\title{
A Holocene pollen record from Mboandong, a crater lake in lowland Cameroon
}

\author{
Keith Richards ${ }^{1}$ \\ KrA Stratigraphic, Deganwy, Conwy, North Wales, United Kingdom
}

\begin{abstract}
Mboandong is a small crater lake situated approximately $30 \mathrm{~km}$ to the north of Mount Cameroon. A core $13 \mathrm{~m}$ in length was collected from the lake centre in December 1981 with the objective of studying Holocene vegetation change in the lowlands of West Cameroon. Radiocarbon dating indicates that the base on the core is close to 7000 years old. Volcanic eruptions of Mount Cameroon between $c .7000$ and 6000 years ago are indicated by ash deposits which are overlain by diatomite. Otherwise the lake sediments consist of fine-grained organic mud, with no obvious sedimentary breaks or any sign of the lake having dried out. A fairly rapid sedimentation rate of at least $1 \mathrm{~m}$ per 500 years is indicated. Predominantly forested conditions existed throughout much of the Holocene, possibly of the Congo type (everwet) rainforest prior to $c .2700 \mathrm{cal}$ yr BP. At this time man was probably encouraging fruits of the 'atili' tree Canarium schweinfurthii as an oil-rich food. A major increase in Poaceae pollen after c. 2500 cal yr BP is most probably linked to a drying climate, as has now been inferred at numerous sites in tropical West Africa. An increase in pollen from regrowth and semi-deciduous trees possibly indicates a change to an Atlantic type (more seasonal) rainforest after this time. This climate change probably led to subsequent forest clearance, perhaps linked to the southwards migration of the Bantu people and spread of iron technology. Increased numbers of Elaeis guineensis pollen recorded after 1700 cal yr BP are indicative of cultivation. The oil palm appears to have replaced the atili tree as an oil-rich food source.
\end{abstract}

\subsection{INTRODUCTION}

The fact that major changes in climate and vegetation occurred in Africa during the Quaternary is now well established, with evidence from a large number of sites from around the continent (e.g. Dupont et al. 2000; Rossignol-Strick and Duzer 1979; Lézine et al. 2013b, 2019; Maley and Brenac 1998; Miller and Gosling 2014; Vincens et al. 1999; Sowunmi 1981; Talbot et al. 1984). Hamilton (1976), in a review of botanical and zoological evidence, however, had proposed that the forested areas of present-day Cameroon were part of a refugium where forest had remained relatively unaffected by periods of climatic drying during the Quaternary. A primary aim of this study was to collect a core from this suggested refugium region of Cameroon in order to determine the extent, if any, of vegetation change by means of pollen analysis (Figure 1). Mboandong was chosen for a number of reasons. A variety of lakes in Cameroon have been described, for example by Gèze (1943), Green (1972) and Corbet et al. (1973). Of these lakes, Barombi Mbo was too

\footnotetext{
${ }^{1}$ Other affiliation: Department of Geography and Planning, University of Liverpool, Liverpool, United Kingdom
} 


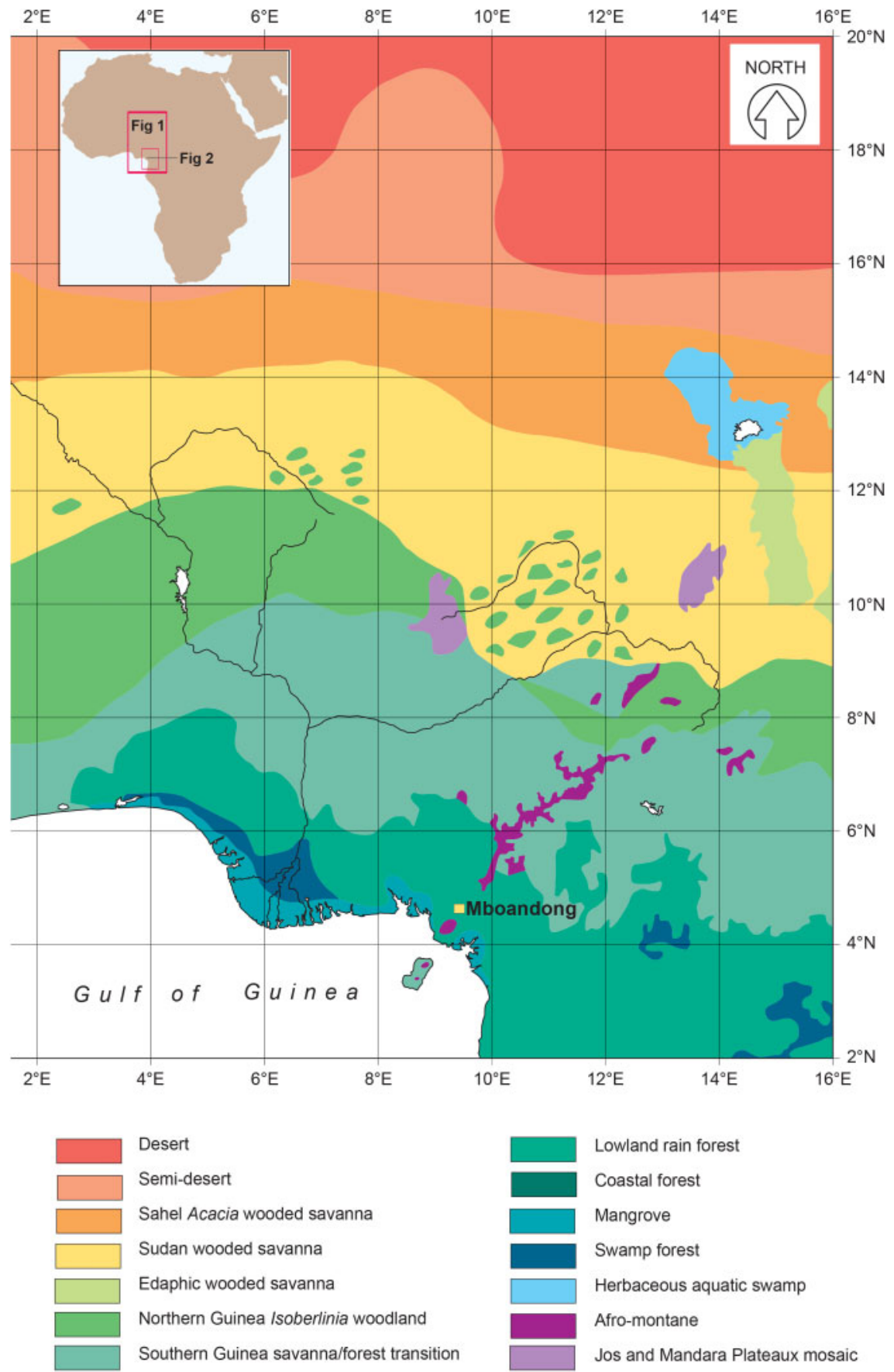

Figure 1. Simplified map of West African vegetation (based on Keay 1959; White 1983) showing the Mboandong study site location. 
deep for coring at the time and Barombi Kotto was excluded as its shores and island are inhabited and it was a known centre for schistosomiasis (Awo et al. 2018, 2020; Duke and Moore 1971; Zahra 1953). Mboandong is only $5 \mathrm{~m}$ deep (Green 1972), relatively undisturbed by man and accessible by road. The base of the core has been dated within the range of 6480 to $7020 \mathrm{cal}$ yr BP and therefore provides a record of more or less the last 7000 years. 'Mbo' is the local name for 'lake' hence there is no need to add the prefix of 'lake' to Mboandong (Corbet et al. 1973).

\subsection{REGIONAL SETTING}

Mboandong $\left(4.4500^{\circ} \mathrm{N}, 9.2689^{\circ} \mathrm{E}\right)$ is situated in a shallow crater at about $120 \mathrm{~m}$ altitude on the low-lying plain between Mount Cameroon, the Roumpi Hills and Mount Koupé. The area consists mainly of basaltic rocks and evidence for widespread volcanic activity is provided by the hundred or so historic eruption points (Figure 2), several of which now contain crater lakes. Geological information from Mboandong is lacking but the lake may be of the same approximate age as nearby Barombi Kotto, a larger crater lake, created by explosive action during a geologically recent, presumably Quaternary, eruptive phase (Gèze 1943). Mboandong lies in the rain shadow of Mount Cameroon. Annual rainfall is the region of 2000 to $2600 \mathrm{~mm}$ per year (Hawkins and Brunt 1965); this compares with rainfall typically of 8500 to $10,300 \mathrm{~mm}$ per year to the west of the mountain, in the Atlantic coastal region. The wettest months tend to be July, August and September and the driest December, January and February. Even so, Richards (1963) noted that this region of Cameroon, which falls within the 'sous climat bas Camerounian' of Aubréville (1949), is characterised by the absence of a well-defined and prolonged dry season.

A detailed study of the vegetation of Cameroon was carried out by Letouzey (1968) and the main vegetation types are shown in Figure 1. The western boundary of the Southern Bakundu Forest Reserve is only $2 \mathrm{~km}$ from Mboandong. In a survey of vegetation carried out in 1948, Richards (1963) described the Bakundu forest as 'essentially similar' to other African Mixed Rain Forests, though not uniform in structure or floristic composition. Patches of high forest with emergent trees occurred in a mosaic, together with gaps with less tall trees and climbing plants. The exceptionally high floristic diversity of this area prompted Richards (1963) to consider the region a likely refugium. Since the 1948 study of Bakundu, timber extraction has increased substantially and this has also been the case for the area around Mboandong. Figure 3 shows the vegetation in the immediate vicinity of the lake before 1976, but large tracts of forest have been entirely removed and plantations extended since that date. In December 1981, the lake was surrounded by a narrow band of rainforest including both primary and secondary forest elements. Most distinctive were Musanga cecropioides, Raphia hookeri and Ceiba pentandra (Baker et al. 1986). A few patches of relatively undisturbed rainforest remained on the eastern side of the lake. A small area had been cleared on the north western shore for cocoa plantations. Away from the lake, large areas of land had been cleared for cultivation including oil palm, banana, plantain, cocoa, rubber and cassava.

\subsection{METHODS}

A single core $13 \mathrm{~m}$ in length was collected from the approximate centre of the lake, using a modified Livingstone mud sampler (Livingstone 1955; Walker 1964) operated from a raft. Aluminium casing was used to prevent the coring rods from bending and to ensure that each section of the core was collected from precisely the same location. A continuous sediment core was obtained except for the interval 12.50-12.00 m which was lost. The core was extruded and described in the field, before being sealed in polythene sheet to prevent contamination and 


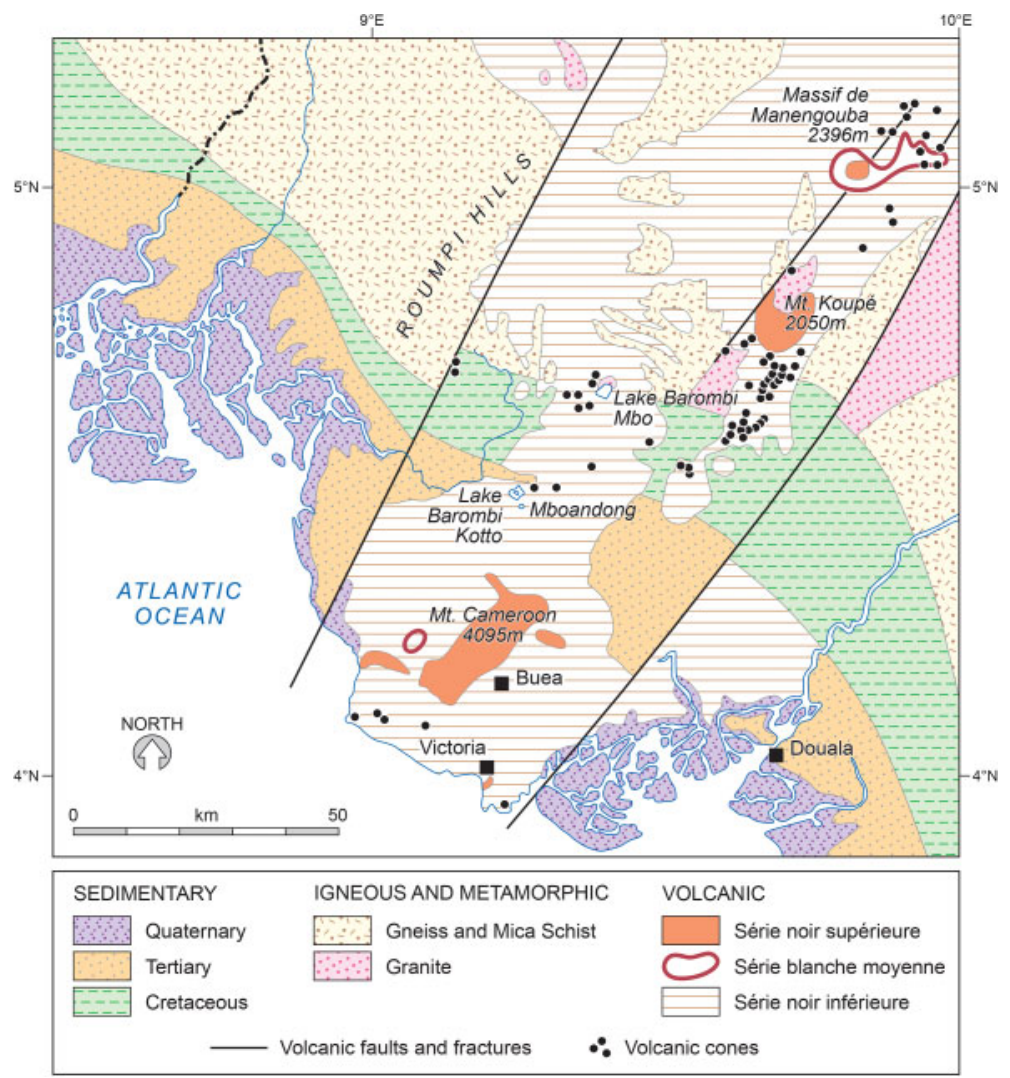

Figure 2. Geological map of South-west Cameroon (modified after Gèze 1943) showing key geographical features and study sites. Note: the many additional volcanic cones formed in recent years in the Mount Cameroon vicinity (e.g. Wantim et al. 2013) are not shown.

oxidation during transportation. Twenty-seven samples were prepared for pollen analysis using $\mathrm{KOH}(10 \%)$, cold $\mathrm{HCl}(20 \%)$ and warm $\mathrm{HF}(40 \%)$ following the methods described by Moore and Webb (1978). One Stockmarr Lycopodium tablet (batch 201890) was added to $30 \mathrm{~g}$ dry weight of sample. Samples were sieved using ultrasound to remove particles less than $5 \mu \mathrm{m}$ in diameter and subject to brief acetolysis (using a 9:1 mix of acetic anhydride and sulphuric acid) and oxidation (using sodium chlorate and concentrated $\mathrm{HCl}$ ). Residues were mounted in silicone oil. A minimum of 400 pollen and spores were counted for each sample, with the exception of $10.89 \mathrm{~m}$ where recovery of pollen was particularly low. All laboratory preparations were carried out at Hull University. Microscopy was carried out in 1983 and 1984 at Hull University and Duke University. Selected grains were photographed from ancient and modern reference material to ensure consistency in identification (Supporting Online Material [SOM] Plates I-V). Three bulk mud samples were radiocarbon dated and results recalibrated by Beta Analytic in October 2020 using the High Probability Density Range method (Bronk Ramsey 2009). The results of the pollen analysis were constrained by CONISS cluster analysis (Grimm 1987). The core was kept in cold storage at Hull University but unfortunately deteriorated and was disposed of around the year 2010 (Jane Bunting, personal communication, 2020). 


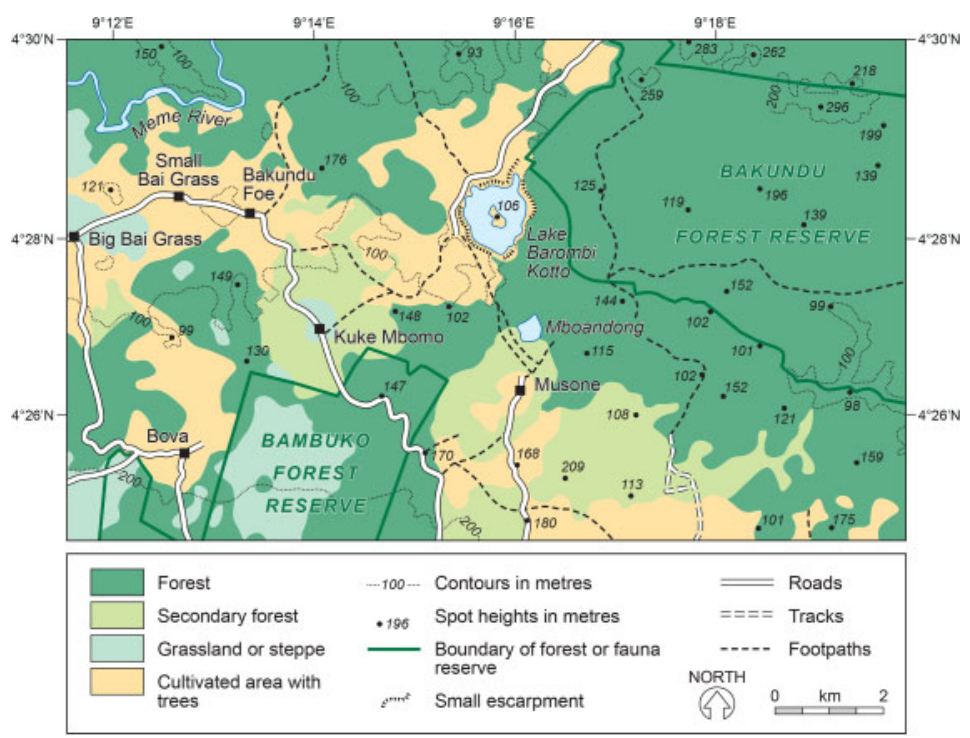

Figure 3. Map showing vegetation and land-use around Mboandong prior to 1976. Adapted from 1:50,000 Map of Cameroon (Buea-Douala NB-32-IV sheets 1c and 1d), Centre Géographique National, Yaoundé.

Table 1. Radiocarbon ages from Mboandong bulk mud samples. Ages were calibrated by Beta Analytic Inc. in October 2020 using the INTCAL13 database and High Probability Density Range Method (HPD). No adjustments for Reservoir Effect were made.

\begin{tabular}{llccc}
\hline Depth $(\mathrm{m})$ & Reference & ${ }^{14} \mathrm{C}$ age & $\delta^{13} \mathrm{C}(\%)$ & cal yrs BP (95\%) \\
\hline $4.37-4.48$ & Beta-11198 & $2380 \pm 70$ & -26.01 & 2310 to 2720 cal BP \\
$8.37-8.48$ & Beta-11197 & $4520 \pm 90$ & -33.29 & 4870 to 5330 cal BP \\
$12.93-12.98$ & Harwell-5028 & $5930 \pm 110$ & -32.30 & 6480 to 7020 cal BP \\
\hline
\end{tabular}

\subsection{SEDIMENT DESCRIPTION AND RADIOCARBON DATING}

Between $13 \mathrm{~m}$ and $10 \mathrm{~m}$ the core exhibits several distinct lithological changes. At least two bands of volcanic ash occur (12.71 to $12.50 \mathrm{~m}, 12.00$ to $11.80 \mathrm{~m}$ and 11.64 to $11.00 \mathrm{~m}$ ). Samples from these intervals were prepared for pollen analysis but recovery was too low to give a useable count. The upper ash layer is directly overlain by a single bed of diatomite $(11.00 \mathrm{~m}$ to $10.05 \mathrm{~m})$. Above $10.05 \mathrm{~m}$ the core consists of uniform fine-grained organic mud. Results of radiocarbon dating are shown in Table 1 . The base of the core produced a conventional ${ }^{14} \mathrm{C}$ age of $5930 \pm 110 \mathrm{BP}$ which is within the range ( $95 \%$ confidence) of 6480 to $7020 \mathrm{cal} \mathrm{yr} \mathrm{BP.} \mathrm{The} \mathrm{radiocarbon} \mathrm{dates} \mathrm{appear} \mathrm{to}$ be fairly consistent and give no indication of any serious errors. The $\delta^{13} \mathrm{C}$ values of -26.01 to $-32.30 \%$ suggest no significant old carbon contamination. Calcareous deposits of Cretaceous age do occur in the south-west province of Cameroon but the water catchment of Mboandong is more or less restricted to the overlying volcanic strata. Inwashing of old carbon from calcareous rock is therefore considered unlikely, especially as there are no rivers inflowing to the lake. No traces of modern rooted vegetation or other sources of possible modern carbon contamination were observed. 


\subsection{PALYNOLOGY}

\subsubsection{General observations}

The results of the pollen analysis are given in Figure 4. Assigned names have been amended to follow the format of the African Pollen Database (Vincens et al. 2007). The pollen taxa have been grouped in 'ecological groups'. However, as pollen determination has often only been possible to generic or even family level, this is problematic when a recorded pollen type could have originated from more than one life form or vegetation type. The groupings in Figure 4, therefore, represent the life forms and vegetation types from which the recorded pollen types are most probably derived, although this is an over-simplification. In making this zonation, reference has been made, in particular, to Hutchinson and Dalziel (1954-1968), Hall and Swaine (1981), Letouzey (1968, 1979), Nielson (1965) and Sowunmi (1981). Quite high percentages of the pollen sum are taken up by Alchornea and Urticaceae undiff. but no real ecological significance can be attributed to these widely fluctuating occurrences. Alchornea pollen is very probably derived mostly from Alchornea cordifolia, a common understory rainforest tree, which occurs also in swamp forest, montane forest and savanna. In Africa, Urticaceae are mainly forest herbs, some of which are very high pollen producers (Hamilton 1982). The pollen of this group is very small, often less than $10 \mu \mathrm{m}$ in diameter, and may therefore have been subject to losses during decantation and ultrasonic sieving, although all samples were processed using identical methods. A complete list of pollen and spore taxa recorded is provided in SOM (Appendix I).

\subsubsection{Pollen in relation to local vegetation}

Due to time constraints, it was not possible to obtain information on modern pollen rain from the Mboandong locality. However, the near-surface sample from the lake core $(0.14 \mathrm{~m})$ probably gives a reasonable indication of modern pollen deposition at the site, and can be compared with floral data from the nearby Bakundu Forest Reserve. The floral data from Bakundu (Richards 1963 ) included all tree taxa over $30 \mathrm{~cm}$ girth, listed as number of boles in 15 size classes ranging from $30 \mathrm{~cm}$ to over $4.0 \mathrm{~m}$. These data were re-calculated and compared to the pollen data from Mboandong (Richards 1987), grouped by family rather than genera or species, except where a finer taxonomic division could be detected in the pollen record. Percentage girth data from Bakundu were plotted against the percentage of total tree pollen at $0.14 \mathrm{~m}$ in the lake core. Considerable over representation in the pollen sample was shown by Elaeis guineensis, Alchornea and Urticaceae undiff. These taxa are part of the 'local' pollen element and were not recorded in the 'regional' tree data from Bakundu. The pollen to vegetation relationship can be summarised as follows: 1) Taxa which feature strongly in the pollen record but have limited or no representation at Bakundu. These include a) Trees associated with semi-deciduous forest, secondary forest or understory conditions such as Ceiba pentandra, Macaranga, Lophira, Bosqueia, Musanga, Antidesma and Celtis; b) Trees associated with swampy conditions such as Uapaca, Raphia and Palmae. These taxa are most probably derived predominantly from the forest edge, swamp forest or disturbed forest and therefore represent the local pollen element, mainly from around the study site. Rhizophoraceae pollen is most probably sourced from Anopyxis klaineana, a rainforest tree (a mangrove pollen source is unlikely). 2) Taxa which are represented in both the pollen record and the vegetation survey, and are therefore likely to be good indicators of the regional pollen component. These include: Anacardiaceae, Combretaceae, Euphorbiaceae e.g. Phyllanthus, Rubiaceae, Pycnanthus, Coulea, Vitex and Sapotaceae. 3) Tree taxa recorded in 


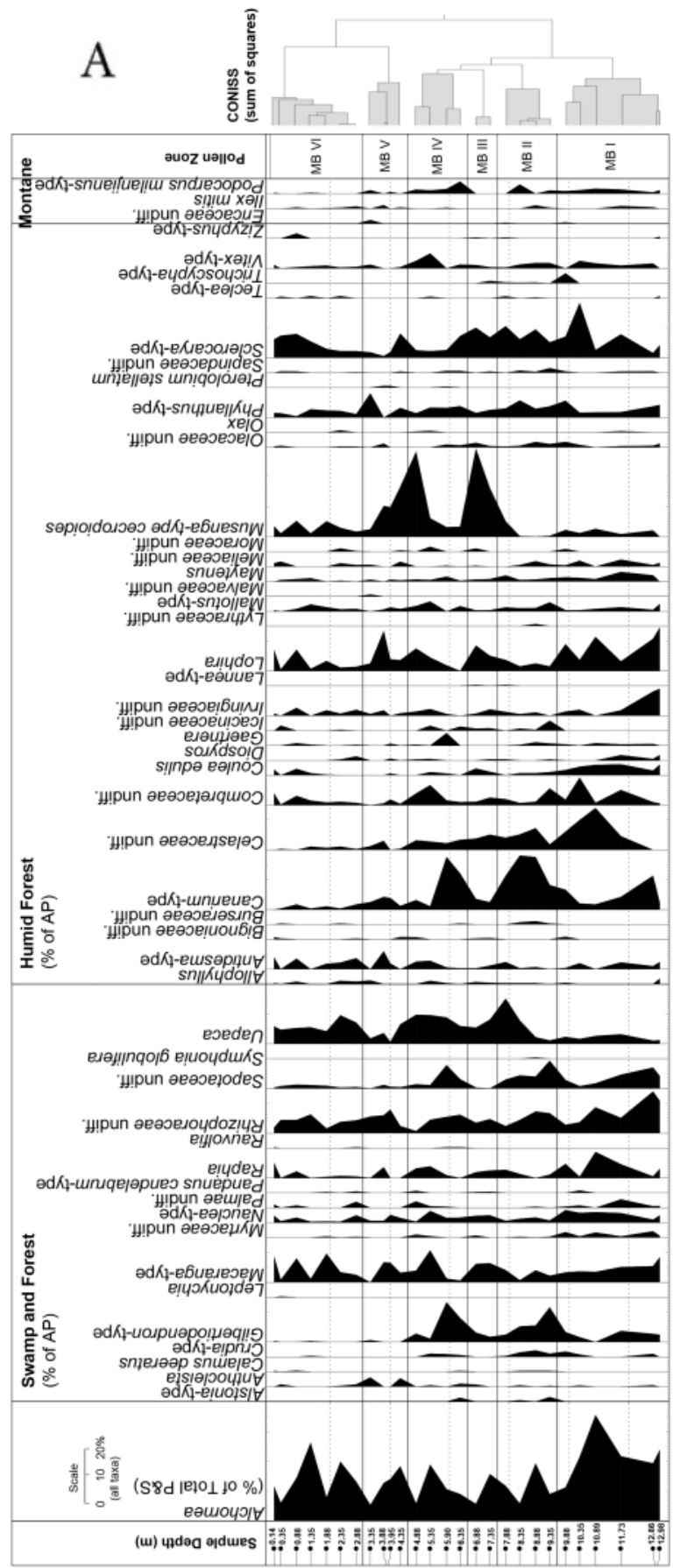

(Continued) 


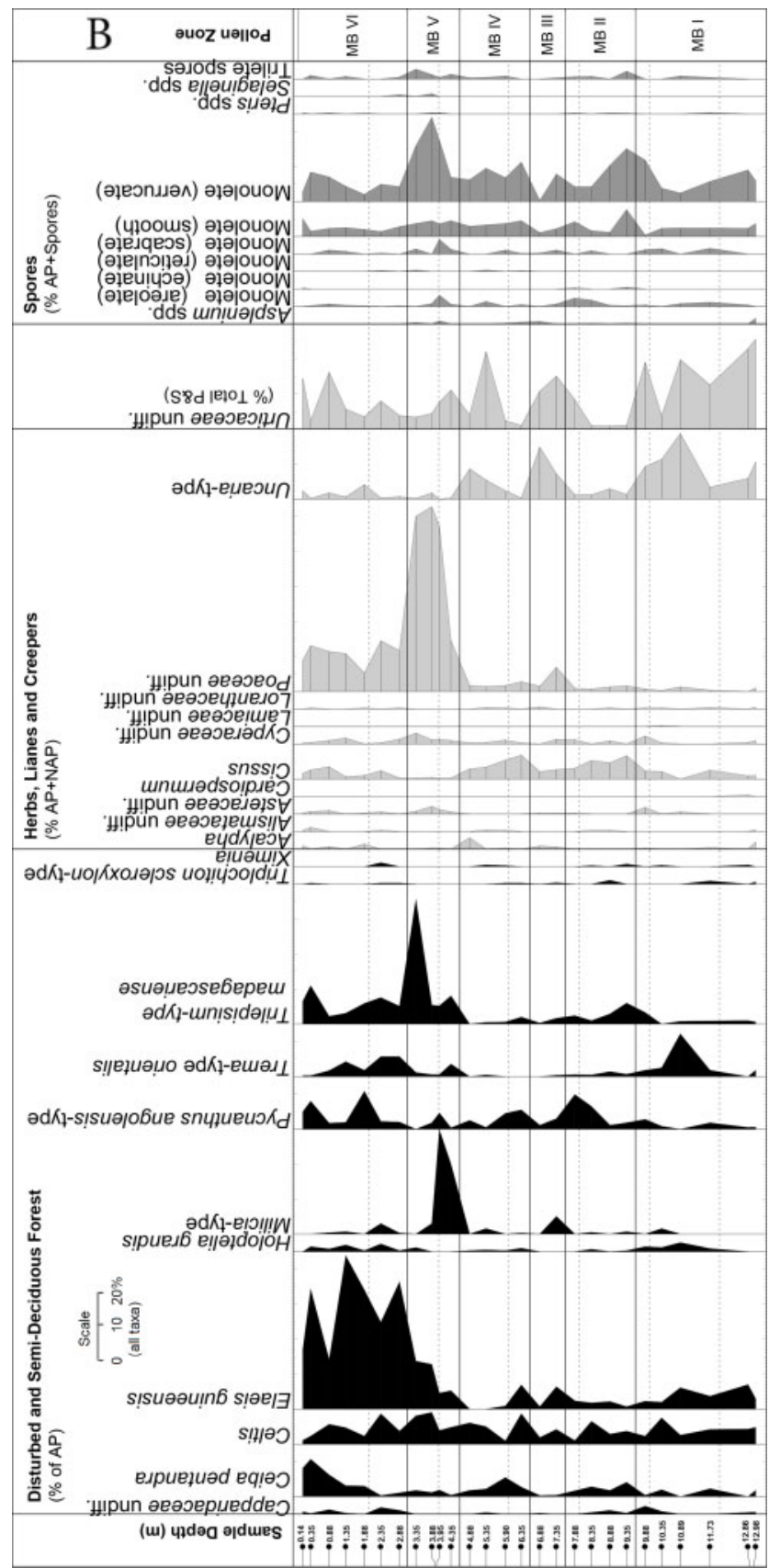

Figures 4A and 4B. Diagrams showing the pollen and spores recorded in the Mboandong study. Tree and shrub pollen are shown as a percentage of Arboreal Pollen (AP). Non Arboreal Pollen (NAP) from herbs and lianes are calculated as a percentage of AP+NAP. Spores are calculated as a percentage of AP+Spores. Alchornea, Urticaceae undiff. and undetermined pollen are excluded from all sums. 
the Bakundu forest that show little or no representation in the pollen record, such as Olacaceae, Diospyros, Irvingiaceae, Cola, Annonaceae, Flacourtiaceae, Sterculiaceae, Clusiaceae, Lecythidaceae, Alstonia, Violaceae and Lauraceae. These taxa may be entomophilous, have low pollen production and/or poor dispersal, have poor preservational properties or may have pollen that is not readily distinguishable. Most of the trees and shrubs represented in the pollen study were also identified in an ecological survey of the riparian vegetation around Lake Barombi Kotto, situated around $2 \mathrm{~km}$ to the north of Mboandong (Awo 2018).

\subsubsection{Pollen diagram zonation}

In this section values for trees and shrubs are percentages of Arboreal Pollen (AP) whereas values for non-arboreal pollen (NAP) are percentages of AP+NAP. Values for spores are percentages of $\mathrm{AP}+$ Spores. Pollen of Alchornea, Urticaceae undiff. and undetermined taxa are excluded from all sums. Values given for the 'ecological groups' are calculated in the same way. Zones are assigned on the basis of CONISS clusters (Figure 4). Age ranges shown are estimates based on extrapolation of the radiocarbon ages (Table 1).

\subsubsection{Zone MB I: 12.98 -9.88 m (6800-5600 BP)}

This interval is characterised by the presence of common Alchornea (11-36\%) and Urticaceae undiff. (up to 26\%). Swamp forest elements are represented more or less consistently at between $28 \%$ and $36 \%$, with a slightly lower abundance of $19 \%$ at $10.35 \mathrm{~m}$. Important components in this interval are Rhizophoraceae undiff. (3-14\%), Macaranga-type (3-8\%), Gilbertiodendron-type (up to $4 \%$ ) and Sapotaceae undiff. (up to 7\%). Lowland forest elements are co-dominant in this interval with abundances of between $43 \%$ and $61 \%$, with taxa including Canarium-type (up to $11 \%$ ), Lophira (up to 15\%), Irvingiaceae undiff. (up to 9\%) and Olacaceae undiff. (less than 1\%). Minor peaks occur in Meliaceae undiff. and Coulea edulis. Semi-deciduous forest elements are consistently represented at between $14 \%$ and $25 \%$. Montane elements are consistent but rare with Podocarpus milanjianus-type occurring at $2 \%$ or less. Other taxa of note are Uncaria-type (up to $19 \%$ ) which accounts for a significant proportion of NAP $(21 \%$ at $10.89 \mathrm{~m})$, and Celastraceae undiff. (up to 14\%). Fern spores account for between $7 \%$ and $14 \%$ of the sum. Of the disturbance indicators, Poaceae pollen is rare (less than 1\%) as are Elaeis guineensis (2-7\%), Trema-type orientalis (up to 12\%) and Musanga-type cecropioides (up to 3\%).

\subsubsection{Zone MB II: 9.35-7.88 m (5400-4700 BP)}

This interval is characterised by a predominance of pollen most probably from lowland forest and swamp arboreal sources. Frequent Canarium-type pollen (up to 18\%) occurs together with common Gilbertiodendron-type (up to 12\%) and Sapotaceae undiff. (up to 9\%). Pollen from likely swamp elements is common, occurring fairly consistently at $28 \%$ to $37 \%$. Important components of this group are Uapaca which reaches $15 \%$ at $7.88 \mathrm{~m}$ and Rhizophoraceae undiff. (up to 7\%). The lowland forest elements are dominant in this interval, ranging between 42 and $56 \%$, and include Maytenus (up to 2\%), Antidesma-type (up to 2\%) and Olacaceae undiff. (up to $2 \%$ ) and many other rare but consistent taxa. Other important pollen types present include two types thought likely to originate from the Anacardiaceae family: Sclerocarya-type is consistently common (5-11\%), and Trichoscypha-type occurs rarely (less than 1\%) but is more or less restricted to this interval of the core, as is Icacinaceae undiff. (3\% at $9.35 \mathrm{~m})$. Pollen of Cissus (up to $7 \%$ ), derived from a climber in the Vitaceae family, and fern spores (up to 20\%) are consistent in this interval. Semi-deciduous forest elements are less common but occur consistently at between $15 \%$ and 22\% and include Pycnanthus angolensis-type (up to 10\%). Poaceae, Elaeis guineensis and Musanga-type cecropioides pollen are present in very low numbers. 


\subsubsection{Zone MB III: 7.35-6.88 m (4400-4100 BP)}

Elaeis guineensis pollen ranges from $1 \%$ or less to $6 \%$ at $7.35 \mathrm{~m}$. A slight increase in Poaceae pollen $(7 \%)$ occurs in the same sample, which is also marked by the first major increase in Musanga comp. (16\%).

\subsubsection{Zone MB IV: 6.35-4.88 m (3700-2800 BP)}

This interval is characterised by a common presence of pollen of Canarium-type (up to 18\%), Gilbertiodendron-type (up to 13\%) as well as a strong input from the Urticaceae, Rubiaceae and Euphorbiaceae families. A slight increase in Podocarpus milanjianus-type occurs. Poaceae and Elaeis guineensis pollen occur but are not frequent (maximum of 3\% and 7\% respectively). Monolete fern spores are consistently present (6-11\%).

\subsubsection{Zone $M B V:$ 4.35-3.35 m (2500-1900 BP)}

This interval is characterised by the overwhelming abundance of grass pollen (family Poaceae) which shows a gradual increase towards the top of the interval where it accounts for 50 to $53 \%$ of the pollen sum. Consistent Elaeis guineensis (up to 14\%) is also present together with other disturbed forest types such as Musanga-type cecropioides (up to 17\%). This interval is also marked by an increase in fern spores (up to 32\%). Lowland rainforest elements are also reduced (24-40\%) and are characterised by a large number of rare taxa such as Lophira (up to $13 \%$ ) and Antidesma-type (up to 6\%). Also of interest is the presence of pollen types associated with disturbed or semi-deciduous forest (up to 62\%), notably Trilepisium-type madagascariense [=Bosqueia angolensis] (up to 36\%), which occurs with Milicia-type [=Chlorophora] (up to $30 \%$ ), Trema-type orientalis (up to 4\%) and Celtis (up to 9\%).

\subsubsection{Zone MB VI: 2.88-0.14m (1700-100 BP)}

This interval is characterised by the presence of abundant Elaeis guineensis (up to 44\%), and by common Poaceae (up to 15\%) but with lower proportions of grass pollen than in Zone MB V. Pollen of understory and/or secondary forest trees, such as Alchornea (up to 26\%), is well represented. Lowland rainforest elements occur fairly consistently (18-40\%) as do swamp forest elements $(13-27 \%)$. Also notably common is tree pollen from disturbed or semi-deciduous vegetation (up to 69\%), including Trilepisium-type madagascariense (up to 11\%), Pycnanthus angolensis-type (up to $11 \%$ ) and Celtis (up to 9\%). Pollen of Ceiba pentandra, another semi-deciduous tree, occurs commonly (up to $11 \%$ ) towards the top of this interval.

\subsection{INTERPRETATION}

\subsubsection{The pollen and sedimentary record}

Zone MB I (12.98-9.88 m; 6800-5600 BP) contains a mixture of sediment types including at least two volcanic ash deposits and thin layers of organic mud, which are overlain by a $1 \mathrm{~m}$ thick deposit of diatomite $(11.00 \mathrm{~m}$ to $10.05 \mathrm{~m})$. In all likelihood, the diatomite has formed in response to an increased availability of silica, provided by volcanic ash fall, as described by Wallace et al. (2006). It is likely that the ash originates from nearby Mount Cameroon which has been active during the Late Quaternary: at least 19 eruptive events of the mountain have been documented during the last 2500 years (Global Volcanism Program 2013). No confirmed eruption dates are known from the earlier part of the Holocene. On the basis of the radiocarbon age obtained at the base of the core, the volcanic ash in the core would have been deposited between approximately 7000 and 6000 years ago. This is several thousand years after the ash layers recorded in core at Barombi Mbo (Maley et al. 1991). Interpretation of the vegetation is problematic due to the very high numbers of Alchornea and Urticaceae pollen. The vegetation 
close to the site probably consisted of mixed primary and secondary rainforest with some swamp elements. The very slight increase of Trema-type orientalis and Uncaria-type pollen at $10.89 \mathrm{~m}$, immediately above the uppermost of the volcanic ash bands, may be due to localised volcanic disturbance. Very low levels of Musanga-type cecropioides and Poaceae pollen argue against widespread forest disturbance at this time.

Zone MB II (9.35-7.88 m; 5400-4700 BP) is characterised primarily by humid forest and swamp tree taxa, whereas Zone MB III (7.35-6.88 m; 4400-4100 BP) probably marks the first significant forest disturbance around the study site, after $4400 \mathrm{BP}$, on the basis of frequent Musanga-type cecropioides pollen. A mechanism for disturbance cannot be established with certainty, but man cannot be ruled out. The overall pollen assemblages are consistent with predominantly lowland humid rainforest with swamp and regrowth components. Zone MB IV (6.35-4.88 m; 3700-2800 BP) contains mostly tree pollen indicating closed forest. The co-occurrence of Caesalpiniaceae (Gilbertiodendron-type), Canarium-type and Podocarpus milanjianus-type in this interval at Mboandong is explained by Giresse et al. (2020) as 'cloud forest effect' due to increased condensation associated with cooling temperatures. This may also account for the relatively high numbers of fern spores recorded.

The main feature of Zone MB V (4.35-3.35 m; 2500-1900 BP) is the major increase in pollen from Poaceae and semi-deciduous tree taxa such as Trilepisium-type madagascariense and Milicia-type. Swamp elements and lowland rainforest elements are reduced, whereas fern spores are frequent. The overall assemblages from this interval conclusively show a change from humid rainforest to more open vegetation, characterised mainly by Poaceae and semi-deciduous trees. The uppermost interval Zone MB VI (2.88-0.14 m; 1700-100 BP) shows a marked decrease in Poaceae pollen offset by significantly increased Elaeis guineensis. Most tree pollen taxa are represented although it is not possible to determine if these arboreal taxa (e.g. Rhizophoraceae undiff., Macaranga-type and Uapaca) are derived from the immediate vicinity of the lake or from further afield. Reduced percentages of lowland and swamp forest taxa are balanced by an increase in semi-deciduous elements. The overall assemblage points to forest disturbance with likely cultivation of oil palm, Elaeis guineensis.

\subsubsection{Vegetation representation}

\subsubsection{Swamp pollen}

A fairly consistent input of pollen from swamp sources suggests that a fringing element of swamp forest has persisted around the lake for much of the last 7000 years. Scattered Raphia palms overhang the lake at the present time although, from the low levels of Raphia pollen recorded, it is unlikely that extensive 'raphiales'swamp communities existed by the lake. Rhizophoraceae pollen is probably derived predominantly from trees such as Anopyxis klaineana which are known to occur in freshwater conditions, rather than as a result of long-distance transport from mangrove.

\subsubsection{Montane pollen}

Podocarpus pollen is an important indicator of Afromontane vegetation (Lézine et al. 2013a). Podocarpus milanjianus [=P. latifolius, Migliore et al. 2020] grows on several West African mountains but it is apparently absent from Mount Cameroon (Letouzey 1968). Low levels of this easily dispersed pollen type occur in the Mboandong core, but had Podocarpus occurred on Mount Cameroon at any time during the last 7000 years, the amount of Podocarpus pollen recorded in the lake is likely to have been greater. The small amount of Podocarpus pollen present in the lake core may be derived from the Roumpi Hills, some $15 \mathrm{~km}$ to the north or from peaks such as Mount Koupé which supports well-developed montane vegetation (Baker 1986). 


\subsubsection{Dry forest pollen}

Trees such as Triplochiton scleroxylon and Celtis, which are characteristic of semi-deciduous forest, may also occur in disturbed areas within humid forest. Trilepisium-type madagascariense pollen, common in the upper regions of the core in Zones MB-V and MB-VI (after 2500 cal yr BP), is most probably derived from Bosqueia angolensis, a tree characteristic of semi-deciduous forest patches within the humid rainforest zone. Pollen of Milicia-type is probably derived from the semideciduous tree Chlorophora excelsa (Moraceae), although the pollen is also morphologically similar to Antiaris toxicaria. Milicia-type pollen is notably rare in the core with the exception being a brief peak at around $4 \mathrm{~m}(c .2500-2300 \mathrm{BP})$. This may be related to a short-lived abundance of these trees at around the time when the first signs of major forest disturbance are visible, or a response to a drying climate. The slight increase in Ceiba pentandra pollen in the uppermost few samples in the core may be due to species protection because of its useful 'kapok'. The consistent presence of Ceiba pentandra pollen appears to confirm the view of Baker (1965) who considered the species native to West Africa; Hutchinson and Dalziel (1954-1968) and others believed it to be an ancient introduction from tropical America.

\subsection{DISCUSSION}

\subsubsection{Floristic affinities of forest communities}

The pollen assemblages indicate that predominantly humid rainforest has been present in the Mboandong region for the last 7000 years, although it is unclear whether the rainforest represented is of the Atlantic or Congo type, as defined by Letouzey (1968). Two important tree pollen taxa well represented in the lower intervals of the core are Gilbertiodendron-type and Sapotaceae undiff. The pollen attributed to Gilbertiodendron-type is fairly large and coarsely striate but several other genera within the Caesalpiniaceae produce similar pollen. These include Berlinia, Didelotia, Microberlinia and others which are all genera characteristic of the Atlantic type forest, although none of these trees were found during the floristic survey of Bakundu by Richards (1963). Gilbertiodendron-type pollen occurs only very rarely in the upper reaches of the core. If, therefore, forest of the Atlantic type has persisted in the Mboandong region for the last 6000 or more years, the marked decline in Gilbertiodendron-type pollen after $c .3000$ BP must be linked either to the direct felling of these leguminous trees or the overwhelming dominance of pollen such as Poaceae and Elaeis guineensis.

Another possibility is that the abundance of Gilbertiodendron-type pollen in the lower regions of the core is from Gilbertiodendron dewevrei. This species is characteristic of Congo type forests and is now mainly restricted to the Dja region of south-east Cameroon, (Letouzey 1968). It is possible, therefore, that the former distribution of this forest type may have extended further westwards than at present. The abundance of pollen from the Sapotaceae family shows an almost identical pattern of distribution in the core to Gilbertiodendron comp. Both are more common in the basal parts of the core, with peaks at $8.35 \mathrm{~m}$ and $5.90 \mathrm{~m}$. It is possible that the Sapotaceae pollen in the basal parts of the core could be derived from Baillonella toxisperma, a large forest emergent which shows similar relict distribution patterns to Gilbertiodendron dewevrei in Cameroon (Letouzey 1968). Baillonella toxisperma was the only Sapotaceae species of note recorded at Bakundu (Richards 1963), occurring as a single, very large individual tree. It is certainly possible that forest of Congo floristic affinities could have occurred in the vicinity of Mboandong, particularly between c. 5400 and 2500 BP. The 'relict' characteristics evident both at Bakundu (Richards 1963) and in the present distributions shown by Gilbertiodendron dewevrei and Baillonella toxisperma (Letouzey 1968) are certainly consistent with a more extensive distribution of Congo type forest in the past. 
Letouzey (1968) also lists Alchornea floribunda and Trichoscypha congoensis [=T. acuminata] as characteristic species of the Congo type forest, although they also occur in Atlantic type forest. Alchornea pollen is common throughout the Mboandong core and is therefore of little interpretative value. Pollen attributed to Trichoscypha-type is present in the core but only in low quantities in Zones MB I, II and III where Gilbertiodendron comp. and Sapotaceae are common. Its presence, therefore, is consistent with, but not indicative of, a Congo type forest. Similarly, pollen of Cissus and Celastraceae undiff. are also common in Zones MB I, II, III and IV. These are also taxa considered characteristic of Congo forest by Letouzey (1968) but they are not exclusive to it. In view of the large degree of species overlap between the Congo and Atlantic forest types, the distinction between the two forest types could at least partly be due to the higher degree of forest disturbance in the western regions of the country, as noted by Letouzey (1968). The boundary between Zones MB-IV and MB-V which sees a sharp decline in the abundance of Gilbertiodendron-type and Sapotaceae pollen also coincides with increased evidence of forest disturbance. Additionally, the Atlantic forest occurs in the region with a more seasonal (i.e. periodically dry) climate whereas the Congo forest occurs in the more equatorial (i.e. everwet) regions. Hence a climatic control may partly account for the present distributions and species composition of Atlantic and Congo type forests.

\subsubsection{Climate change or man-made change?}

The cause of the vegetation change evident at Mboandong after $2500 \mathrm{cal}$ yr BP is the subject of ongoing debate. Increasing aridity is invoked by Maley (2002) and Lebamba et al. (2012) as the primary cause of the 'late Holocene rainforest crisis' between 2500 and 2000 years BP. Bostoen et al. $(2013,2015)$ provided supporting evidence based on linguistics. Garcin et al. (2018), in a study from Lake Barombi, however, considered that the 'late Holocene rainforest crisis' after $2600 \mathrm{cal}$ yr BP was a consequence of human activity, and resulted from the Bantu expansion, although this view was countered by Clist et al. (2018). The balance of pollen-based evidence from multiple sites presented by Giresse et al. (2020), however, does support a drying climate as the initial cause of the change from forest-dominated to grass-dominated vegetation around 2500 years ago. This is a change of emphasis from that previously reported by Richards (1986, 1987) but is made on the basis of the wealth of new information from the region that has become available since that time.

The significant increase of Elaeis guineensis pollen (up to 23\%) after c. $1700 \mathrm{BP}$ suggests that cultivation of oil palm was taking place in the Mboandong region. Low levels of this pollen type in the lower reaches of the core may represent the natural presence in forest clearings. The relationship between the oil palm (Elaeis guineensis) and the 'atili tree' (Canarium schweinfurthii) is also relevant (Lézine et al. 2013b; Maley and Chepstow-Lusty 2001; Sowunmi 1999). At Mboandong, based on pollen evidence, Canarium appears to have been more important in the past than at the present time, as Canarium-type pollen accounts for $13 \%$ of the pollen sum at $8.35 \mathrm{~m}$, around 5000 years ago, but is absent from the uppermost levels of the core, where Elaeis is an important element. Based on comparisons with reference pollen, it is almost certain that the pollen recorded in the core is from Canarium schweinfurthii. It is therefore highly likely that Canarium was a significant oil-food source in Cameroon, very probably an example of 'vegeculture' which has subsequently declined with Elaeis cultivation within the last 2000 years.

\subsection{CONCLUSIONS}

Early Holocene volcanic activity in the region, presumably of Mount Cameroon, is indicated by the deposits of volcanic ash in the Mboandong core deposited between $c .7000$ and 6000 years 
ago. Silica from the ash enabled a bloom of diatoms, resulting in a $1 \mathrm{~m}$ thick diatomite deposited after c. $6000 \mathrm{cal}$ yr BP. Since this time, the Mboandong lake sediments consist of fine-grained organic mud, but with no evidence of any hiatus or other significant stratigraphic change. No signs of the lake having dried out within the last 7000 years were observed. From extrapolation of the radiocarbon ages, a fairly rapid sedimentation rate of at least $1 \mathrm{~m}$ per 500 years is indicated, equivalent to $c .2 \mathrm{~mm}$ per year.

The pollen record indicates that predominantly forested conditions have prevailed in the vicinity of the study site throughout much of the Holocene. Between $c .7000$ and $2500 \mathrm{cal}$ yr BP, the dominant forest elements were derived from humid rainforest and swamp forest, with important components derived from the Caesalpiniaceae and Sapotaceae families. There is a possible affinity with Congo type (everwet) rainforest although this is speculative. During this time, man was probably encouraging the tree Canarium schweinfurthii as an oil-rich food source. After c. $2500 \mathrm{cal} \mathrm{yr}$ BP increased proportions of regrowth and semi-deciduous trees are represented in the pollen record, possibly indicating a change to an Atlantic type (more seasonal) rainforest, as occurs in undisturbed vegetation in West Cameroon at the present time. Pollen from the oil palm Elaeis guineensis occurs throughout the Mboandong core, initially in low numbers, suggesting that oil palm at first grew naturally as secondary forest element. Significantly increased numbers of Elaeis pollen recorded after $1700 \mathrm{cal}$ yr BP are indicative of cultivation. The oil palm Elaeis guineensis appears to have replaced the atili tree Canarium schweinfurthii as a source of oil-rich food.

A major increase in Poaceae pollen at c. $2500 \mathrm{cal}$ yr BP is most probably linked to a drying climate, as has now been inferred at numerous sites in tropical West Africa. This climate change probably led to subsequent forest clearance, shown by an increase in pollen from semi-deciduous trees such as Bosqueia angolensis, which probably exploited openings within the forest canopy. This time-line is broadly consistent with dates for iron working in West Africa, which suggests that iron technology and forest clearance were related events, but which followed on from a climatic shift. It is quite conceivable that a significant drying within northern and western Africa within the last few thousand years prompted movement of people southwards to more humid latitudes. It is probable that iron technology was also disseminated at this time, perhaps linked to the migration of the Bantu people. This regional picture from West Africa is supported by the pollen data from Mboandong and suggests that a changing climate first affected the regional vegetation around 2500 years ago, followed by forest clearance and crop cultivation within the last 2000 years.

\section{ACKNOWLEDGEMENTS}

This work was carried out as an MSc project in the early 1980's at the Department of Geography, University of Hull under the guidance of the late John R. Flenley and at Duke University, assisted by the late Daniel A. Livingstone. This paper is dedicated to the fond memory of both JRF and DAL whose support and encouragement made this study possible. Partial funding was received from The Nuffield Foundation. Margaret Adebisi Sowunmi (University of Ibadan) provided assistance with some pollen identification and Miranda Awo (University of Buea) provided upto-date information on the vegetation, plant-pollen relationships and limnology of the study region. Ron Hatfield of Beta Analytic Inc. assisted with calibration of radiocarbon ages. Figures 2 and 3 were re-drawn by Alison Davies of The Mapping Company, UK, from originals drawn at Hull University, Department of Geography. The core was collected by members of the 1981-82 Hull University Cameroon Expedition: Richard Baker, Stephen Compton, Sean Edwards, David Newsome, Keith Richards, Carrie Rimes, Howard Smith and Ollie Smith. 


\section{REFERENCES}

Aubréville, A., 1949, Climats. Fôrets et desertification de l'Afrique tropicale. Paris : Sociéte d'Editions Géographiques, Maritimes et Coloniales, Paris.

Awo M.E., 2018, Water quality, riparian vegetation and algal ecological assessment of Lake Barombi Kotto, Cameroon. PhD Thesis, University of Buea, Cameroon.

Awo, M.E., Tabot, P.T., Goodenough, N. and Ambo, F.B., 2018, Spatiotemporal variation of phytoplankton community structure in the crater lake Barombi Kotto, Cameroon. International Journal of Current Research in Biosciences and Plant Biology, 5(2), pp. 36-55, 10.20546/ijcrbp.2018.502.005.

Awo, M.E., Fonge, B.A., Tabot, P.T. and Akoachere, J.T.K., 2020, Water quality of the volcanic crater lake, Lake Barombi Kotto, in Cameroon. African Journal of Aquatic Sciences, 45(4), pp. 401-411, 10.2989/16085914.2020.1737799

Baker, H.G., 1965, The evolution of the cultivated Kapok tree; a probable west African product. In Ecology and Economic Development in Tropical Africa edited by Brokensha, D., pp.185216..Institute of International Studies, University of California.

Baker, R.G.E, 1986, Introduction: The Biogeography of Cameroon. University of Hull Department of Geography Miscellaneous Series, 30, pp. 1-13.

Baker, R.G.E., Richards, K., and Rimes, C.A., 1986, The Hull University Cameroun Expedition: 1981-82 Final Report. University of Hull Department of Geography Miscellaneous Series, 30, pp. 1-109.

Bostoen, K., Clist, B., Doumenge, C., Grollemund, R., Hombert J.-M., Muluwa, J.K. and Maley, J. 2015, Middle to Late Holocene paleoclimate change and the early Bantu expansion in the rain forests of western central Africa. Current Anthropology, 56(3), pp. 354-384, 10.1086/681436.

Bostoen, K., Grollemund, R., Hombert J.-M. and Muluwa, J.K., 2013, Climate-induced vegetation dynamics and the Bantu Expansion: Evidence from Bantu names for pioneer trees (Elaeis guineensis, Canarium schweinfurthii, and Musanga cecropioides). Comptes Rendus Geoscience, 345, pp. 336-349, 10.1016/j.crte.2013.03.005.

Bronk Ramsey, C., 2009, Bayesian analysis of radiocarbon dates. Radiocarbon 51(1), pp. 337-360, 10.1017/S0033822200033865.

Clist, B., Bostoen, K., de Maret, P., Eggert, M.K., Höhn, A., Mindzié, C.M., Neumann, K. and Seidensticker, D., 2018, Did human activity really trigger the late Holocene rainforest crisis in Central Africa? Proceedings of the National Academy of Sciences, 115(21), pp. E4733-E4734, 10.1073/pnas.1805247115.

Corbet, S.A., Green, J., Griffith, J. and Betney, E., 1973, Ecological studies on crater lakes in west Cameroon: Lakes Kotto and Mboandong. Journal of Zoology, 170, pp. 309-324, 10.1111/j.1469-7998.1973.tb01380.x.

Duke, B.C.L. and Moore, P.J., 1971, The control of Schistosoma haematobium in west Cameroon. Transactions of the Royal Society of Tropical Medicine and Hygiene, 65, pp. 841-843, 10.1016/0035-9203(71)90106-4.

Dupont, L.M., Jahns, S., Marret, F. and Ning, S. 2000, Vegetation change in equatorial West Africa: time-slices for the last 150ka. Palaeogeography, Palaeoclimatology, Palaeoecology, 155, pp. 95-122, 10.1016/S0031-0182(99)00095-4.

Garcin, Y., Deschamps, P., Ménot, G., de Saulieu, G., Schefuß, E., Sebag, D., Dupont, L.M., Oslisly, R., Brademann, B., Mbusnum, K.G., Onana, J.-M., Akon, A.A., Epp, L.S., Tjallingii, R., Strecker, M.R., Brauer, A. and Sachse, D., 2018, Early anthropogenic impact on Western Central African rainforests 2,600 y ago. Proceedings of the National Academy of Sciences, 115(13), pp. 3261-3266, 10.1073/pnas.1715336115.

Gèze, B., 1943, Géographie physique et géologie du Cameroun occidental. Mémoires du Muséum Nationale d'Histoire Naturelle Paris, 17, pp. 1-272. 
Giresse, P., Maley, J. and Chepstow-Lusty, A., 2020, Understanding the $2500 \mathrm{yr}$ BP rainforest crisis in West and Central Africa in the framework of the Late Holocene: pluridisciplinary analysis and multi-archive reconstruction. Global and Planetary Change, 192, article: 103257, 10.1016/j.gloplacha.2020.103257.

Global Volcanism Program, 2013, Cameroon (224010) in Volcanoes of the World, v. 4.9.1 (17 Sep 2020) Smithsonian Institution. Downloaded 09 Oct 2020. https://volcano.si.edu/volcano.cfm? $\mathrm{vn}=224010$

Green, J., 1972, Ecological studies on crater lakes in west Cameroun: zooplankton of Barombi Mbo, Mboandong, Lake Kotto and Lake Soden. Journal of Zoology, 166, pp. 283-301, 10.1111/j.1469-7998.1972.tb03099.x.

Grimm, E.C., 1987, CONISS: a FORTRAN 77 program for stratigraphically constrained cluster analysis by the method of incremental sum of squares. Computers and Geosciences, 13(1), pp. 13-35, 10.1016/0098-3004(87)90022-7.

Hall, J.B. and Swaine, M.D., 1981, Distribution and Ecology of Vascular Plants in a Tropical Rain Forest: Forest Vegetation in Ghana. Geobotany Series 1 (The Hague and London: Junk).

Hamilton, A.C., 1976, The significance of patterns of distribution shown by forest plants and animals in tropical Africa for the reconstruction of Upper Pleistocene palaeoenvironments: a review. Palaeoecology of Africa, 9, pp. 63-97.

Hamilton, A.C., 1982, Environmental History of East Africa. A Study of the Quaternary, (London: Academic Press).

Hawkins, P. and Brunt, M., 1965, The Soils and Ecology of West Cameroon, Volumes 1-2, Food and Agriculture Organization of the United Nations, report 2083, Rome, pp. 1-516.

Hutchinson, J. and Dalziel, J.M., 1954-1968, Flora of West Tropical Africa, Edition 1, (London: Crown Agents for Overseas Governments).

Keay, R.W.J., 1959, An Outline of Nigerian Vegetation, (Lagos: Federal Government Printer) pp. 1-34.

Lebamba, J., Vincens, A. and Maley, J., 2012, Pollen, vegetation change and climate at Lake Barombi Mbo (Cameroon) during the last ca. 33,000 cal. yr BP: a numerical approach. Climate of the Past, 8, pp. 59-78, 10.5194/cp-8-59-2012.

Letouzey, R., 1968, Etude Phytogéoqraphique du Cameroun, Encyclopédie Biologique, volume LXIX, Paris.

Letouzey, R., 1979, Végétation. In Atlas de la République Unie du Cameroon, edited by Laclavère, G. (Paris: Editions Jeune Afrique).

Lézine, A.-M., Assi-Kaudjhis, C., Roche, E., Vincens, A. and Achoundong, G., 2013a, Towards an understanding of West African montane forest response to climate change. Journal of Biogeography, 40(1), pp. 183-196, 10.1111/j.1365-2699.2012.02770.x.

Lézine, A.-M., Holl, A.F.C., Lebamba, J., Vincens, A., Assi-Khaudjis, C., Février, L. and Sultan, E., 2013b, Temporal relationship between Holocene human occupation and vegetation change along the northwestern margin of the Central African rainforest. Comptes Rendus Geoscience, 345(7-8), pp. 327-335, 10.1016/j.crte.2013.03.001.

Lézine, A.-M., Izumi, K., Kageyama, M. and Achoundong, G., 2019, A 90,000-year record of Afromontane forest responses to climate change. Science 363, pp. 177-181, 10.1126/science.aav6821.

Livingstone, D.A., 1955, A light-weight piston sampler for lake deposits. Ecology, 36, pp. 137-139, 10.2307/1931439.

Maley, J., 2002, A catastrophic destruction of African forests about 2,500 years ago still exerts a major influence on present vegetation. Institute of Development Studies Bulletin, 33(1), pp. 13-30, 10.1111/j.1759-5436.2002.tb00003.x.

Maley, J. and Brenac, P., 1998, Vegetation dynamics, palaeoenvironments and climatic changes in the forests of West Cameroon during the last 28,000 years. Review of Palaeobotany and Palynology, 99, pp. 157-88, 10.1016/S0034-6667(97)00047-X. 
Maley, J., Livingstone, D.A., Giresse, P., Brenac, P., Kling, G., Stager, C., Thouveny, N., Kelts, K., Haag, M., Fournier, M., Bandet, Y., Williamson, D. and Zogning, A., 1991, West Cameroon Quaternary lacustrine deposits: preliminary results. Journal of African Earth Sciences, 12 (1-2), pp. 147-157, 10.1016/0899-5362(91)90065-7.

Maley, J. and Chepstow-Lusty, A., 2001, Elaeis guineensis Jacq. (oil palm) fluctuations in central Africa during the late Holocene: climate or human driving forces for this pioneering species? Vegetation History and Archaeobotany, 10, pp. 117-20, 10.1007/PL00006920.

Migliore, J., Lézine, A.-M. and Hardy, O.J., 2020, The recent colonization history of the most widespread Podocarpus tree species in Afromontane forests. Annals of Botany, 126, pp. 73-83, 10.1093/aob/mcaa049.

Miller, C.S. and Gosling, W.D., 2014, Quaternary forest associations in lowland tropical West Africa. Quaternary Science Reviews, 84, pp. 7-25, 10.1016/j.quascirev.2013.10.027.

Moore, P.D. and Webb, J.A., 1978, An Illustrated Guide to Pollen Analysis, (London: Hodder and Stoughton), pp. 1-133.

Nielson, M.S., 1965, Introduction to the Flowering Plants of West Africa, (London: University of London Press), pp. 1-246.

Richards, K., 1986, Preliminary results of pollen analysis of a 6,000 year core from Mboandong, a crater lake in Cameroun. University of Hull Department of Geography Miscellaneous Series, 30, pp. 14-28.

Richards, K., 1987, A palynological study of the Late Quaternary vegetational history of Mboandong, a lowland lake in Cameroun. MS. Thesis, University of Hull.

Richards, P.W., 1963, Ecological notes on West African vegetation, II. Lowland forest of the Southern Bakundu Forest Reserve. Journal of Ecology, 51, pp. 123-149, 10.2307/2257510.

Rossignol-Strick, M. and Duzer, D., 1979, West African vegetation and climatic change since 22,500 BP from deep-sea cores palynology. Pollen et Spores 21, pp. 105-134.

Sowunmi, M.A., 1981, Aspects of the late Quaternary vegetational changes in West Africa. Journal of Biogeography, 8, pp. 457-474, 10.2307/2844565.

Sowunmi, M.A., 1999, The significance of the oil palm (Elaeis guineensis Jacq.) in the late Holocene environments of west and west central Africa: a further consideration. Vegetation History and Archaeobotany, 8, pp. 199-210, 10.1007/BF02342720.

Talbot, M.R., Livingstone, D.A., Palmer, P.G., Maley, J., Melack, J.M., Delibrias, G. and Guilliksen, S., 1984, Preliminary results from sediment cores from Lake Bosumtwi, Ghana. Palaeoecology of Africa, 16, pp. 173-192.

Vincens, A., Lézine, A.M., Buchet, G., Lewden, D. and Le Thomas, A., 2007, African pollen database inventory of tree and shrub pollen types. Review of Palaeobotany and Palynology, 145(1-2), pp. 135-141, 10.1016/j.revpalbo.2006.09.004.

Vincens, A., Schwartz, D., Elenga, H., Reynaud-Farrera, I., Servant, M. and Wirrmann, D., 1999, Forest response to climate changes in Atlantic Equatorial Africa during the last 4000 years BP and inheritance on the modern landscapes. Journal of Biogeography, 26, pp. 879-85, 10.1046/j.1365-2699.1999.00333.x.

Walker, D., 1964, A modified Vallentyne mud sampler. Ecology, 45, pp. 642-644, $10.2307 / 1936118$.

Wallace, A. R., Frank, D. G. and Founie, A., 2006, Freshwater diatomite deposits in the western United States. US Department of the Interior, US Geological Survey Fact Sheet 2006-3044.

Wantim, W.N., Kervyn, M., Ernst, G.G.J, Del Marmol, M.-A., Suh, C.E. and Jacobs, P., 2013, Morpho-Structure of the 1982 Lava Flow Field at Mount Cameroon Volcano, West-Central Africa. International Journal of Geosciences, 4, pp. 564-583, 10.4236/ijg.2013.43052.

White, F., 1983, The vegetation of Africa, (Paris: UNESCO).

Zahra, A., 1953, Some notes on the incidence of Schistosomiasis in the southern Cameroons. West African Medical Journal, 2(1), pp. 26-29. 


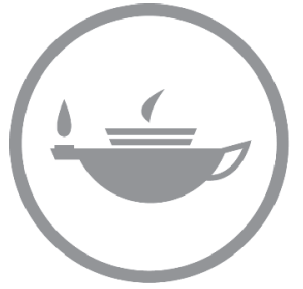

Taylor \& Francis Taylor \& Francis Group http://taylorandfrancis.com 